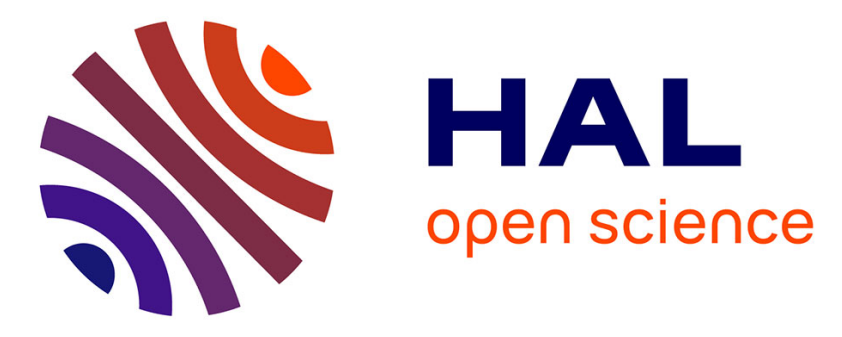

\title{
Intercluster exchanges leading to hydride-centered bimetallic clusters: a multi-NMR, X-ray crystallographic, and DFT study
}

Yu-Jie Zhong, Jian-Hong Liao, Tzu-Hao Chiu, Ying-Yann Wu, Samia Kahlal, Michael J Mcglinchey, Jean-Yves Saillard, C W Liu

\section{To cite this version:}

Yu-Jie Zhong, Jian-Hong Liao, Tzu-Hao Chiu, Ying-Yann Wu, Samia Kahlal, et al.. Intercluster exchanges leading to hydride-centered bimetallic clusters: a multi-NMR, X-ray crystallographic, and DFT study. Dalton Transactions, 2021, 50 (13), pp.4727-4734. 10.1039/d1dt00072a . hal-03194301

\section{HAL Id: hal-03194301 \\ https://hal.science/hal-03194301}

Submitted on 23 Apr 2021

HAL is a multi-disciplinary open access archive for the deposit and dissemination of scientific research documents, whether they are published or not. The documents may come from teaching and research institutions in France or abroad, or from public or private research centers.
L'archive ouverte pluridisciplinaire HAL, est destinée au dépôt et à la diffusion de documents scientifiques de niveau recherche, publiés ou non, émanant des établissements d'enseignement et de recherche français ou étrangers, des laboratoires publics ou privés. 


\title{
Intercluster Exchanges Leading to Hydride-Centered Bimetallic Clusters: An X-ray Crystallographic, Multi-NMR and DFT Study
}

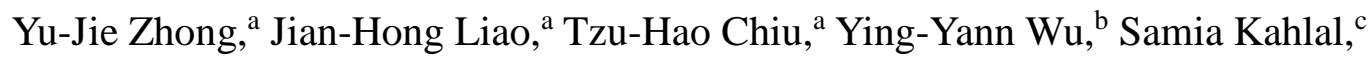 \\ Michael J. McGlinchey, ${ }^{\mathrm{d}}$ Jean-Yves Saillard ${ }^{\mathrm{c}}$ and C. W. Liu*a \\ ${ }^{a}$ Department of Chemistry, National Dong Hwa University, Hualien 974301, Taiwan, \\ Republic of China.E-mail: chenwei@mail.ndhu.edu.tw \\ ${ }^{b}$ Institute of Chemistry, Academia Sinica, Taipei 11528, Taiwan, Republic of China. \\ ${ }^{c}$ Univ Rennes, CNRS, ISCR-UMR 6226, F-35000 Rennes, France. \\ ${ }^{d}$ UCD School of Chemistry, University College Dublin, Belfield, Dublin 4, Ireland
}

\begin{abstract}
Encouraged by the successful syntheses of alloy nanoclusters (or nanoparticles) via intercluster (or interparticle) reactions, herein we apply this methodology to prepare a series of bimetallic hydride clusters. Mixing of two clusters, $\left[\mathrm{Ag}_{7}(\mathrm{H})\left\{\mathrm{E}_{2} \mathrm{P}\left(\mathrm{O}^{i} \mathrm{Pr}\right)_{2}\right\}_{6}\right](\mathrm{E}$ $=\mathrm{S}, 1$; Se, 3) and $\left[\mathrm{Cu}_{7}(\mathrm{H})\left\{\mathrm{E}_{2} \mathrm{P}\left(\mathrm{O}^{i} \mathrm{Pr}\right)_{2}\right\}_{6}\right](\mathrm{E}=\mathrm{S}, 2$; Se, 4), yields two series of hydridecentered bimetallic clusters, $\left[\mathrm{Cu}_{\mathrm{x}} \mathrm{Ag}_{7-\mathrm{x}}(\mathrm{H})\left\{\mathrm{E}_{2} \mathrm{P}\left(\mathrm{O}^{i} \mathrm{Pr}\right)_{2}\right\}_{6}\right](\mathrm{x}=0-7$; E = S, 5; Se, 6). Their compositions are fully characterized by positive-mode ESI-MS spectrometry, multi-NMR spectroscopy, and the structures of $\left[\mathrm{Cu}_{6} \mathrm{Ag}(\mathrm{H})\left\{\mathrm{S}_{2} \mathrm{P}\left(\mathrm{O}^{i} \mathrm{Pr}\right)_{2}\right\}_{6}\right]$ (5a) and $\left[\mathrm{CuAg}_{6}(\mathrm{H})\left\{\mathrm{Se}_{2} \mathrm{P}\left(\mathrm{O}^{i} \mathrm{Pr}\right)_{2}\right\}_{6}\right]$ (6a) by single crystal X-ray diffraction. The presence of individual compounds in solution is the result of a (dynamic) chemical equilibrium primarily driven by metal exchanges. In fact, the process of inter-cluster exchange of 1 and 2 leading to hydride-centered bimetallic clusters 5 can be monitored by concentration-dependent ${ }^{31} \mathrm{P}$ NMR spectroscopy of which the higher concentration of 1 in the reaction, the closer to its resonance will be the distribution, in accord with Le Chatelier's principle. The dynamic equilibrium is further confirmed by $2 \mathrm{D}$ exchange spectroscopy that reveals a stepwise process involving one metal exchange at a time. DFT calculations on a model series of clusters 6 show that silver prefers occupying the inner tetrahedral positions, while copper favors capping positions, in full agreement with the crystal structure of $5 \mathrm{a}$ and $6 \mathrm{a}$.
\end{abstract}

\section{Introduction}

The topic of alloy nanoclusters (NCs) is currently a subject of active research, because it allows tuning (sometimes dramatically modifying) the properties of their homometallic counterparts. ${ }^{1-4}$ Doping heterometals via galvanic/anti-galvanic exchanges or co-reductions are the most common methods to obtain heterometallic

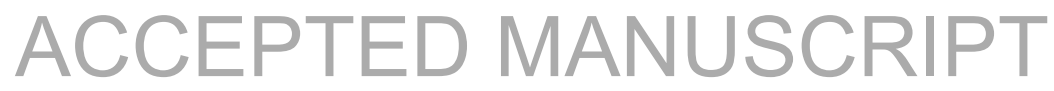


NCs. ${ }^{5-9}$ Zhu and coworkers reported a library of doped Ag$_{29}$ NCs and successfully pushed the heterometallic boundaries to tetrametallic NCs. ${ }^{10}$ Pradeep et al. described the intercluster reaction of $\mathrm{Ag}_{25}(\mathrm{DMBT})_{18}$ and $\mathrm{Au}_{25}(\mathrm{PET})_{18}$ to produce isostructural $\mathrm{Ag}_{\mathrm{m}} \mathrm{Au}_{\mathrm{n}}(\mathrm{SR})_{18}$ species. ${ }^{11-12}$ Based on ESI mass spectrometry experiments, which detected a species corresponding to the $\left[\mathrm{Ag}_{25} \mathrm{Au}_{25}(\mathrm{DMBT})_{18}(\mathrm{PET})_{18}\right]^{2-}$ dianion, an exchange process starting from the approach of two clusters and leading to the alloys was proposed. A possible reaction route of this intercluster alloying reaction was further theoretically studied by Pei et al. ${ }^{13}$ Successful examples produced via intercluster reactions include $A_{2} \mathrm{I}_{22}$ from $\mathrm{Au}_{25}$ and $\operatorname{Ir}_{9},{ }^{14} \mathrm{Au}_{12} \mathrm{Ag}_{32}$ from $\mathrm{Au}_{25}$ and $\mathrm{Ag}_{44},{ }^{15}$ and trimetallic $\mathrm{MAu}_{12} \mathrm{Ag}_{16}(\mathrm{M}=\mathrm{Ni}, \mathrm{Pd}, \mathrm{Pt}) \mathrm{NCs}$ from $\mathrm{MAg}_{28}$ and $\mathrm{Au}_{25}{ }^{16}$ Intercluster reactions also occur on the surface of the NCs such as ligand replacement reactions, which are considered to trigger structural transformations under certain circumstances. ${ }^{17-19}$ In the present study we apply intercluster reactions as the main strategy to generate hydride-centered bimetallic clusters. It appears the latter clusters do not form through ligand exchanges but via direct metal exchanges as demonstrated by solution NMR spectroscopic studies. To the best of our knowledge, this method has not previously been used in the synthesis of bimetallic hydride clusters. Although polyhydrido copper clusters stabilized by chalcogenolates have received tremendous attention due to their potential applications in catalysis, electrocatalytic $\mathrm{CO}_{2}$ reduction, hydrogenation, or energy storage, ${ }^{20-23}$ well-characterized bimetallic hydride clusters of group 11 metals remain scarce partly due to the lack of reliable, convenient synthetic methodologies. ${ }^{24-26}$ Importantly, the method adopted in this report is significantly different from a recent development by Tsukuda and his co-workers on the subject of hydride-mediated cluster growth involving coinage metals. ${ }^{27-28}$

\section{Results and Discussion}

We recently demonstrated that $\mathrm{Cu}_{4} \mathrm{Ag}_{3}(\mathrm{H})\left\{\mathrm{S}_{2} \mathrm{P}\left(\mathrm{O}^{i} \mathrm{Pr}\right)_{2}\right\}_{6}$, in which seven metal atoms constitute a tricapped-tetrahedral framework, $\left(\mu_{3}-\mathrm{Cu}\right)_{3}\left(\mathrm{CuAg}_{3}\right)$, with an encapsulated hydride at the center of $\mathrm{CuAg}_{3}$ tetrahedron, can be isolated from a mixture of $\mathrm{Cu}_{\mathrm{x}} \mathrm{Ag}_{7-}$ $\mathrm{x}(\mathrm{H})\left\{\mathrm{S}_{2} \mathrm{P}\left(\mathrm{O}^{i} \mathrm{Pr}\right)_{2}\right\}_{6}(\mathrm{x}=1-6)$, synthesized by the reaction of $\left[\mathrm{Ag}\left(\mathrm{CH}_{3} \mathrm{CN}\right)_{4}\right] \mathrm{PF}_{6}$, $\left[\mathrm{Cu}\left(\mathrm{CH}_{3} \mathrm{CN}\right)_{4}\right] \mathrm{PF}_{6}, \mathrm{NH}_{4}\left[\mathrm{~S}_{2} \mathrm{P}\left(\mathrm{O}{ }^{i} \mathrm{Pr}\right)_{2}\right]$ and $\mathrm{NaBH}_{4}$ in a 3:4:6:1 molar ratio. ${ }^{24}$ Although both the composition and structure of a hydride-centered bimetallic heptanuclear cluster were unambiguously confirmed by X-ray diffraction, ESI-MS and NMR data from the crystalline products revealed characteristics corresponding to a distribution of hydridecentered bimetallic clusters, $\mathrm{Cu}_{\mathrm{x}} \mathrm{Ag}_{7-\mathrm{x}}(\mathrm{H})\left\{\mathrm{S}_{2} \mathrm{P}\left(\mathrm{O}^{i} \mathrm{Pr}\right)_{2}\right\}_{6}(\mathrm{x}=1-6)$, and suggest the occurrence of intramolecular and/or intermolecular metal exchanges both in solution and in the gas phase. Herein we present the inter-cluster reactions (Scheme 1) of $\left[\mathrm{Ag}_{7}(\mathrm{H})\left\{\mathrm{S}_{2} \mathrm{P}\left(\mathrm{O}^{i} \mathrm{Pr}\right)_{2}\right\}_{6}\right](1)$ and $\left[\mathrm{Cu}_{7}(\mathrm{H})\left\{\mathrm{S}_{2} \mathrm{P}\left(\mathrm{O}^{i} \mathrm{Pr}\right)_{2}\right\}_{6}\right](2),\left[\mathrm{Ag}_{7}(\mathrm{H})\left\{\mathrm{Se}_{2} \mathrm{P}\left(\mathrm{O}^{i} \mathrm{Pr}\right)_{2}\right\}_{6}\right]$ (3) 
and $\left[\mathrm{Cu}_{7}(\mathrm{H})\left\{\mathrm{Se}_{2} \mathrm{P}\left(\mathrm{O}^{i} \mathrm{Pr}\right)_{2}\right\}_{6}\right]$ (4), to form $\left[\mathrm{Cu}_{\mathrm{x}} \mathrm{Ag}_{7-\mathrm{x}}(\mathrm{H})\left\{\mathrm{S}_{2} \mathrm{P}\left(\mathrm{O}^{i} \mathrm{Pr}\right)_{2}\right\}_{6}\right]$ (5) and $\left[\mathrm{Cu}_{\mathrm{x}} \mathrm{Ag}_{7-}\right.$ $\left.x(\mathrm{H})\left\{\mathrm{Se}_{2} \mathrm{P}\left(\mathrm{O}^{i} \mathrm{Pr}\right)_{2}\right\}_{6}\right](6)$, respectively.
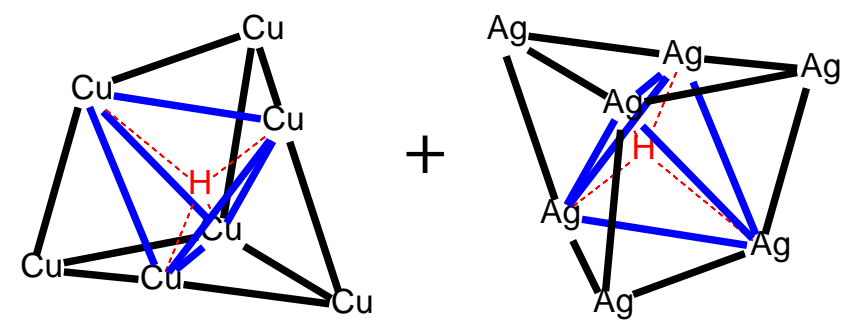

Scheme 1. A schematic diagram of the $\mathrm{Cu}_{7}(\mathrm{H})$ and $\mathrm{Ag}_{7}(\mathrm{H})$ cores in two orientations. Their metal frameworks show the same tricapped tetrahedral geometry.

\section{Characterization of the product distributions in (5) and (6) by multi-NMR spectroscopy and ESI mass spectrometry}

In order to understand the exchange reaction between two different clusters, $\mathrm{Ag}_{7}(\mathrm{H})\left\{\mathrm{S}_{2} \mathrm{P}\left(\mathrm{O}^{i} \mathrm{Pr}\right)_{2}\right\}_{6}$ (1) and $\mathrm{Cu}_{7}(\mathrm{H})\left\{\mathrm{S}_{2} \mathrm{P}\left(\mathrm{O}^{i} \mathrm{Pr}\right)_{2}\right\}_{6}$ (2), which have unique ${ }^{31} \mathrm{P}$ resonances at 108.8 and $103.9 \mathrm{ppm}$, respectively, were synthesized as the starting materials. Time-dependent ${ }^{31} \mathrm{P}$ NMR spectra (Figure S1) in which 1 and 2 were mixed in an equimolar ratio in $\mathrm{CDCl}_{3}$ in an NMR tube were acquired to monitor the reaction, and showed a reassembly process within one minute of mixing. A total of six resonances observed after 10 minutes are virtually identical to those of the previously published bimetallic heptametallic cluster mixtures, $\mathrm{Cu}_{\mathrm{x}} \mathrm{Ag}_{7-\mathrm{x}}(\mathrm{H})\left\{\mathrm{S}_{2} \mathrm{P}\left(\mathrm{O}^{i} \mathrm{Pr}\right)_{2}\right\}_{6}(\mathrm{x}=1-6)$, (5). ${ }^{11 \mathrm{a}}$ Their chemical shifts, line shapes, and relative intensities did not change after 10 minutes, showing that the metal exchange proceeds spontaneously and reaches equilibrium in a very short time. One might therefore anticipate that a variation in the starting proportions of the reactants should influence the chemical equilibrium. To verify this hypothesis, concentration-dependent experiments were performed by mixing 1 and 2 in different ratios; 1:6, 1:4, 1:2, 1:1, 2:1, 4:1, and 6:1 (Figure 1a), and their percentage yields are listed in Table S1. Each NMR spectrum was recorded after one hour of mixing to ensure that the reaction had reached equilibrium. For example, in the case of a 1:6 molar ratio of $\mathrm{Ag}_{7}: \mathrm{Cu}_{7}$, the ${ }^{31} \mathrm{P}\left\{{ }^{1} \mathrm{H}\right\}$ NMR spectrum exhibited three resonances at 103.9, 104.3, and $104.9 \mathrm{ppm}$ (Figure 1b), and the corresponding ${ }^{1} \mathrm{H}$ spectrum showed hydride shifts at 3.58, 5.00 and $5.51 \mathrm{ppm}$, respectively (Figure 1c). Although it is difficult to certify compositions of the corresponding compounds solely from the ${ }^{31} \mathrm{P}$ NMR spectrum, their unique ${ }^{1} \mathrm{H}-\left({ }^{107} \mathrm{Ag} /{ }^{109} \mathrm{Ag}\right)$ coupling patterns and integration ratios displayed in the ${ }^{1} \mathrm{H}$ NMR spectrum provide critical information to formulate compositions unambiguously.

For example, the hydride resonance centered at $5.00 \mathrm{ppm}$ attributable to $\mathrm{Cu}_{6} \mathrm{Ag}(\mathrm{H})$ appears as a pair of doublets centred at the same chemical shift. In this case, the two isotopomers, one containing ${ }^{107} \mathrm{Ag}$, the other ${ }^{109} \mathrm{Ag}$, each bring about doublet splitting 
of the proton resonance. These two spin $1 / 2$ nuclei, which are almost equally abundant (51.82\% and $48.18 \%$, respectively), have magnetogyric ratios that differ only by a factor of 1.145 , that is reflected in their $J$ values whereby couplings to another nucleus (such as ${ }^{1} \mathrm{H}$ or ${ }^{31} \mathrm{P}$ ) are always larger by exactly this factor in the ${ }^{109} \mathrm{Ag}$ case.

A curious feature of spectra involving coupling to silver is beautifully illustrated in the $\mathrm{Cu}_{5} \mathrm{Ag}_{2}(\mathrm{H})$ system centered at $5.51 \mathrm{ppm}$. The three combinations of isotopomers, ${ }^{107} \mathrm{Ag}-{ }^{107} \mathrm{Ag},{ }^{107} \mathrm{Ag}-{ }^{109} \mathrm{Ag}$ and ${ }^{109} \mathrm{Ag}-{ }^{109} \mathrm{Ag}$, exist in the ratio 1:2:1 (approximately); the ${ }^{107} \mathrm{Ag}-{ }^{107} \mathrm{Ag}$ and ${ }^{109} \mathrm{Ag}-{ }^{109} \mathrm{Ag}$ combinations each give rise to 1:2:1 triplets with, as noted above, slightly different $J\left({ }^{1} \mathrm{H}^{-107} \mathrm{Ag}\right)$ and $J\left({ }^{1} \mathrm{H}^{109} \mathrm{Ag}\right)$ values. Concomitantly, coupling in the ${ }^{107} \mathrm{Ag}-{ }^{109} \mathrm{Ag}$ isotopomer appears as a doublet of doublets with, of course, the same $J\left({ }^{1} \mathrm{H}_{-}{ }^{107} \mathrm{Ag}\right)$ and $J\left({ }^{1} \mathrm{H}_{-}{ }^{109} \mathrm{Ag}\right)$ values seen in the aforementioned triplets. The resulting overlap of these three subspectra appears as a pseudo triplet of triplets (Figure S2), as seen in a disilver-hydride reported previously. ${ }^{12}$ Fortuitously, this simplifying pattern continues such that in the $\mathrm{Cu}_{4} \mathrm{Ag}_{3}(\mathrm{H})$ and $\mathrm{Cu}_{3} \mathrm{Ag}_{4}(\mathrm{H})$ clusters the overlapping sets of subspectra appear as a pseudo quartet of quartets and a pseudo quintet of quintets, respectively.

Hence, the combined analysis of both ${ }^{31} \mathrm{P}$ and ${ }^{1} \mathrm{H}$ NMR spectra allows unambiguous identification of the remaining compounds $\mathrm{Cu}_{\mathrm{x}} \mathrm{Ag}_{7-\mathrm{x}}(\mathrm{H})\left\{\mathrm{S}_{2} \mathrm{P}\left(\mathrm{O}^{i} \mathrm{Pr}\right)_{2}\right\}_{6}, \mathrm{x}=5$, 6, and 7 . Based on this principle, all the corresponding ${ }^{31} \mathrm{P}$ NMR resonances of $\mathrm{Cu}_{\mathrm{x}} \mathrm{Ag}_{7-\mathrm{x}}(\mathrm{H})$ $\left\{\mathrm{S}_{2} \mathrm{P}\left(\mathrm{O}^{i} \mathrm{Pr}\right)_{2}\right\}_{6}, \mathrm{x}=0-7$, can be reasonably assigned (Table S2, Figures S3-S8). In short, our experiments indicate that increasing the $\mathrm{Cu}$ content in the starting mixture results in a product distribution exhibiting a larger number of the more shielded ${ }^{31} \mathrm{P}$ resonances; in contrast, a higher concentration of the $\operatorname{Ag}_{7}(\mathrm{H})$ cluster, 1 , in the initial mixture leads to a more downfield-shifted distribution. This phenomenon is a striking illustration of Le Chatelier's principle whereby a system experiencing a disturbance (in this case, a change in concentration) responds so as to establish a new equilibrium position.

Compositions of $\mathrm{Cu}_{\mathrm{x}} \mathrm{Ag}_{7-\mathrm{x}}(\mathrm{H})\left\{\mathrm{S}_{2} \mathrm{P}\left(\mathrm{O}^{i} \mathrm{Pr}\right)_{2}\right\}_{6}(\mathrm{x}=0$ - 7) were further authenticated by the positive-mode ESI mass spectrum (Figure S9). A distribution of ion peaks $\left[\mathrm{Cu}_{\mathrm{x}} \mathrm{Ag}_{7-\mathrm{x}}(\mathrm{H})\left\{\mathrm{S}_{2} \mathrm{P}\left(\mathrm{O}^{\mathrm{i}} \mathrm{Pr}\right)_{2}\right\}_{6}+\mathrm{Ag}^{+}+2\left(\mathrm{H}_{2} \mathrm{O}\right)\right]^{+}, \mathrm{x}=0-7$, was observed from which the most intense band appears at $x=4$. Further crystalline products of $\left[\mathrm{Cu}_{4} \mathrm{Ag}_{3}(\mathrm{H})\right.$ $\left\{\mathrm{S}_{2} \mathrm{P}\left(\mathrm{O}^{\mathrm{i}} \mathrm{Pr}\right)_{2}\right\}_{6}$ ] were collected for mass spectrometry. Surprisingly, the ion peaks displayed a near identical distribution to that found in $\mathrm{Cu}_{\mathrm{x}} \mathrm{Ag}_{7-\mathrm{x}}(\mathrm{H})\left\{\mathrm{S}_{2} \mathrm{P}\left(\mathrm{O}^{i} \mathrm{Pr}\right)_{2}\right\}_{6}$, where $\mathrm{x}=0-7$. These two results strongly suggest that even though the target ion peak $(\mathrm{x}=$ 4 ) is observed in the mass spectrum, the other peaks are apparently generated from a reassembly process in the gas phase.

Following the same synthetic procedure, the diisopropyl diselenophosphateprotected hydride-centered bimetallic clusters, $\mathrm{Cu}_{\mathrm{x}} \mathrm{Ag}_{7-\mathrm{x}}(\mathrm{H})\left\{\mathrm{Se}_{2} \mathrm{P}\left(\mathrm{O}^{i} \mathrm{Pr}\right)_{2}\right\}_{6}(\mathrm{x}=1$ - 6) (6), can also be obtained by the reaction of $\mathrm{Ag}_{7}(\mathrm{H})\left\{\mathrm{Se}_{2} \mathrm{P}\left(\mathrm{O}^{i} \mathrm{Pr}\right)_{2}\right\}_{6}$ (3) ${ }^{13}$ and 
$\mathrm{Cu}_{7}(\mathrm{H})\left\{\mathrm{Se}_{2} \mathrm{P}\left(\mathrm{O}^{i} \mathrm{Pr}\right)_{2}\right\}_{6}$ (4). As with their sulfur analogues, the ${ }^{31} \mathrm{P}$ NMR spectra (Figure 2) were recorded under conditions with different initial concentrations of 3 and 4, and exhibited similar behaviour, whereby the larger the concentration of one of the reactants, the closer to its resonance was the distribution, as a result of equilibrium. However, there was also an overlapping of two of the ${ }^{31} \mathrm{P}$ resonances that could not be unequivocally resolved by cross-comparison with the corresponding ${ }^{1} \mathrm{H}$ spectra (Figures S10-S16) in which a hydride resonance was partially obscured by a methyl signal.

This problem was overcome by preparation of the deuteride analogues, $\mathrm{Cu}_{\mathrm{x}} \mathrm{Ag}_{7-\mathrm{x}}(\mathrm{D})\left\{\mathrm{Se}_{2} \mathrm{P}\left(\mathrm{O}^{i} \mathrm{Pr}\right)_{2}\right\}_{6}$, whose ${ }^{2} \mathrm{H}$ NMR spectra were then acquired. Since the magnetogyric ratios of ${ }^{1} \mathrm{H}$ and ${ }^{2} \mathrm{H}$ differ by a factor of 6.51 , so do their corresponding $J\left({ }^{1} \mathrm{H}_{-}{ }^{109} \mathrm{Ag}\right)$ and $J\left({ }^{2} \mathrm{H}_{-}{ }^{109} \mathrm{Ag}\right)$ values. This decrease in the coupling to silver makes the $J\left({ }^{2} \mathrm{H}_{-}{ }^{107} \mathrm{Ag}\right)$ and $J\left({ }^{2} \mathrm{H}_{-}{ }^{109} \mathrm{Ag}\right)$ values too close to be differentiated, but the doublet observed at $1.22 \mathrm{ppm}$ in ${ }^{2} \mathrm{H}$ NMR spectrum (Figure S17-S18) was found and can be assigned to the $\mathrm{Cu}_{6} \mathrm{Ag}(\mathrm{D})\left\{\mathrm{Se}_{2} \mathrm{P}\left(\mathrm{O}^{i} \mathrm{Pr}\right)_{2}\right\}_{6}$ species, thereby allowing identification of its ${ }^{31} \mathrm{P}$ signal. Chemical shift and coupling constants for these deuterium analogues are listed in Table S3.

An additional feature of series 6 is the presence of another spin $1 / 2$ nucleus, ${ }^{77}$ Se, whose chemical shift also corresponds to the $\mathrm{Ag} / \mathrm{Cu}$ content of the cluster. The ${ }^{1} \mathrm{H},{ }^{31} \mathrm{P}$, ${ }^{109} \mathrm{Ag}$ (Figure S19), and ${ }^{77} \mathrm{Se}$ (Figure S20) chemical shifts and coupling constants of $\mathrm{Cu}_{\mathrm{x}} \mathrm{Ag}_{7-\mathrm{x}}(\mathrm{H})\left\{\mathrm{Se}_{2} \mathrm{P}\left(\mathrm{O}^{i} \mathrm{Pr}\right)_{2}\right\}_{6}(\mathrm{x}=0-7)$, and the ratio of each compound, are listed in Table 1 and Table 2, respectively.

As for 5, compositions of cluster 6 were further authenticated by ESI-MS. The crystalline sample of $\mathrm{CuAg}_{6}(\mathrm{H})\left\{\mathrm{Se}_{2} \mathrm{P}\left(\mathrm{O}^{i} \mathrm{Pr}\right)_{2}\right\}_{6}(6 \mathrm{a})$ was collected to record ESI-MS spectrometry. The positive-ion ESI mass spectrum (Figure S21) displayed the highestintensity ion peak at $\mathrm{m} / \mathrm{z} 2661.1$ (calc. 2661.6), which can be assigned to $\left[\mathrm{CuAg}_{6}(\mathrm{H})\left\{\mathrm{Se}_{2} \mathrm{P}\left(\mathrm{O}^{i} \mathrm{Pr}\right)_{2}\right\}_{6}+\mathrm{Ag}^{+}\right]^{+}$(Figure S22). A distribution of $\left[\mathrm{Cu}_{\mathrm{x}} \mathrm{Ag}_{7-}\right.$ $\left.{ }_{\mathrm{x}}(\mathrm{H})\left\{\mathrm{Se}_{2} \mathrm{P}\left(\mathrm{O}^{i} \mathrm{Pr}\right)_{2}\right\}_{6}+\mathrm{Ag}^{+}\right]^{+}(\mathrm{x}=0-3)$ observed in the spectrum indicates that the rearrangement reaction of the clusters, probably via molecular collisions, occurred in the gas phase. ESI-MS spectrum (Figure 3) of the product from the reaction of 1:1 $\mathrm{Ag}_{7}$, 3: $\mathrm{Cu}_{7}, 4$ displayed a distribution corresponding to the species $\left[\mathrm{Cu}_{\mathrm{x}} \mathrm{Ag}_{7-}\right.$ $\left.{ }_{x}(\mathrm{H})\left\{\mathrm{Se}_{2} \mathrm{P}\left(\mathrm{O}^{i} \mathrm{Pr}\right)_{2}\right\}_{6}+\mathrm{Ag}^{+}\right]^{+}(\mathrm{x}=0-7)$. The latter distribution is close to that already seen in the equimolar reaction of $\mathrm{Ag}_{7}, 1$, and $\mathrm{Cu}_{7}, 2$, to form $\mathrm{Cu}_{\mathrm{x}} \mathrm{Ag}_{7-\mathrm{x}}(\mathrm{H})\left\{\mathrm{S}_{2} \mathrm{P}\left(\mathrm{O}^{i} \mathrm{Pr}\right)_{2}\right\}_{6}$.

\section{Rationalization of the hydride-silver NMR coupling constants, $J\left({ }^{1} \mathrm{H}^{109} \mathrm{Ag}\right)$}

As listed in Table 1, in the $\mathrm{Ag}_{7}(\mathrm{H})\left\{\mathrm{Se}_{2} \mathrm{P}\left(\mathrm{O}^{i} \mathrm{Pr}\right)_{2}\right\}_{6}$ cluster, the hydride-silver coupling constant (40 $\pm 1 \mathrm{~Hz}$ ) seen in both the ${ }^{1} \mathrm{H}$ and ${ }^{109} \mathrm{Ag}$ regimes is the average of seven interactions: [(1 Ag top $\left.\left.+3 \mathrm{Ag}_{\text {cap }}+3 \mathrm{Ag}_{\text {tri }}\right) \div 7\right]$. Of course, these are not all derived from 
a single ${ }^{109} \mathrm{Ag}_{7}$ molecule that represents only a minor fraction of the ${ }^{107} \mathrm{Ag}_{\mathrm{x}}{ }^{109} \mathrm{Ag}_{7-\mathrm{x}}$ isotopomer distribution, which (for simplicity, assuming a 50/50 isotopic ratio) follows the binomial pattern 1:7:21:35:35:21:7:1. The observed $J\left({ }^{1} \mathrm{H}_{-}{ }^{109} \mathrm{Ag}\right)$ values increase from $40 \mathrm{~Hz}$ in the $\mathrm{Ag}_{7}(\mathrm{H})$ cluster to $47 \mathrm{~Hz}, 56 \mathrm{~Hz}$, and $62 \mathrm{~Hz}$ in the $\mathrm{Ag}_{6} \mathrm{Cu}(\mathrm{H})$, $\mathrm{Ag}_{5} \mathrm{Cu}_{2}(\mathrm{H})$ and $\mathrm{Ag}_{4} \mathrm{Cu}_{3}(\mathrm{H})$ systems, respectively, and eventually reach $67 \mathrm{~Hz}$ and 82 $\mathrm{Hz}$ in the $\mathrm{Ag}_{2} \mathrm{Cu}_{5}(\mathrm{H})$ and $\mathrm{AgCu}_{6}(\mathrm{H})$ clusters. It is evident that the sequential replacement by $\mathrm{Cu}$ of capping sites previously occupied by ${ }^{109} \mathrm{Ag}$ brings about a marked increase in the average ${ }^{1} \mathrm{H}-{ }^{109} \mathrm{Ag}$ coupling constant. These data are entirely consistent with the major contributors to the coupling being the ${ }^{1} \mathrm{~J}\left({ }^{1} \mathrm{H}_{-}{ }^{109} \mathrm{Ag}\right)$ interactions with the four directly bonded "tetrahedral" silvers, and that any ${ }^{2} J\left({ }^{1} \mathrm{H}^{109} \mathrm{Ag}\right)$ interactions with the face-capping atoms are zero (or at least very small). Finally, we note that in the analogous sulfur complexes, 5 , the pattern of $J$ values (Table S2) is very similar, but all are slightly larger. $^{24}$

\section{Dynamic equilibrium and intercluster exchanges studied by NMR spectroscopy}

In an experiment starting with equimolar quantities of $\mathrm{Ag}_{7}(\mathrm{H})\left\{\mathrm{S}_{2} \mathrm{P}\left(\mathrm{O}^{i} \mathrm{Pr}\right)_{2}\right\}_{6}, 1$, and $\mathrm{Cu}_{7}(\mathrm{H})\left\{\mathrm{S}_{2} \mathrm{P}\left(\mathrm{O}^{i} \mathrm{Pr}\right)_{2}\right\}_{6}$, 2, which yields the largest number of products, i.e., $\mathrm{Cu}_{\mathrm{x}} \mathrm{Ag}_{7-}$ ${ }_{\mathrm{x}}(\mathrm{H})\left\{\mathrm{S}_{2} \mathrm{P}\left(\mathrm{O}^{i} \mathrm{Pr}\right)_{2}\right\}_{6} \quad\left(\mathrm{x}=0-6\right.$ ), a number of ${ }^{31} \mathrm{P}-{ }^{31} \mathrm{P}\left\{{ }^{1} \mathrm{H}\right\}$ 2D EXSY (exchange spectroscopy) NMR spectra were recorded. In such experiments, the observation of offdiagonal peaks reveals which species are undergoing exchange. A spectrum acquired at ambient temperature with a mixing time of $400 \mathrm{~ms}$ appears as Figure $4 \mathrm{a}$, in which cross peaks appear, for example, between $\mathrm{Ag}_{7} \mathrm{H}$ and $\mathrm{CuAg}_{6} \mathrm{H}, \mathrm{CuAg}_{6} \mathrm{H}$ and $\mathrm{Cu}_{2} \mathrm{Ag}_{5} \mathrm{H}$, $\mathrm{Cu}_{2} \mathrm{Ag}_{5} \mathrm{H}$ and $\mathrm{Cu}_{3} \mathrm{Ag}_{4} \mathrm{H}$, but none between peaks assignable to $\mathrm{Ag}_{7} \mathrm{H}$ and $\mathrm{Cu}_{2} \mathrm{Ag}_{5} \mathrm{H}$, or to $\mathrm{Cu}_{2} \mathrm{Ag}_{5} \mathrm{H}$ and $\mathrm{Cu}_{4} \mathrm{Ag}_{3} \mathrm{H}$. Evidently, on this time scale (400 ms), exchange only takes place between systems that differ in content by only a single silver, and not between species more widely separated. However, as the mixing time increases to $800 \mathrm{~ms}$ (Figure 4b), the appearance of additional (but less intense) cross peaks illustrates that each cluster can be further exchanged, as in $\mathrm{Ag}_{7} \mathrm{H} \rightleftharpoons=\mathrm{Cu}_{2} \mathrm{Ag}_{5} \mathrm{H} ; \mathrm{CuAg}_{6} \mathrm{H} \rightleftharpoons \cdots \cdots \mathrm{Cu}_{3} \mathrm{Ag}_{4} \mathrm{H}$; $\mathrm{Cu}_{2} \mathrm{Ag}_{5} \mathrm{H} \rightleftharpoons \mathrm{Cu}_{4} \mathrm{Ag}_{3} \mathrm{H}$, etc., in each case a difference of two coppers and two silvers. These results unequivocally suggest the operation of a stepwise process, exchanging one metal at a time via $\mathrm{Ag}_{7} \mathrm{H} \rightleftharpoons \cdots \cdots \mathrm{CuAg}_{6} \mathrm{H} \rightleftharpoons \cdots \cdots \mathrm{Cu}_{2} \mathrm{Ag}_{5} \mathrm{H}$, etc. and vice versa.

As to the question of which atom is exchanging, we strongly favor the idea of exchanges occurring at metal centers over that of ligand exchanges; both $\mathrm{d}^{10}-\mathrm{d}^{10}$ and $\mathrm{H}$-Ag interactions are weaker than S-Ag covalent bonding, therefore the metals are more labile than the templating ligands. As a result, the metal exchange process starts from both ends $\left(\mathrm{Cu}_{7}\right.$ and $\left.\mathrm{Ag}_{7}\right)$, gradually approaching the middle, and eventually spontaneously achieves equilibrium. The central limit theorem (CLT) states that the distribution of resonances approximate a normal distribution (bell distribution). ${ }^{14}$ Thus 
the highest intensity of the NMR peaks will fall near the middle of the spectrum, in this case $\mathrm{Cu}_{4} \mathrm{Ag}_{3}(\mathrm{H})\left\{\mathrm{S}_{2} \mathrm{P}\left(\mathrm{O}^{i} \mathrm{Pr}\right)_{2}\right\}_{6}$.

One can discount the existence of ligand exchange in the above-mentioned reactions since this would lead to random exchange between all species, in disagreement with the observed EXSY data. Thus, the $\mathrm{Cu}_{\mathrm{x}} \mathrm{Ag}_{7-\mathrm{x}}(\mathrm{H})\left\{\mathrm{S}_{2} \mathrm{P}\left(\mathrm{O}^{i} \mathrm{Pr}\right)_{2}\right\}_{6}(\mathrm{x}=1-6)$ species are formed through inter-cluster metal exchange processes, and is obviously different from the thioprotected nanoclusters formed through ligand exchanges in the inter-cluster reaction. ${ }^{4,5,15}$

Likewise, the ${ }^{1} \mathrm{H}-{ }^{1} \mathrm{H}$ 2D EXSY NMR spectrum, recorded with a mixing time of 400 ms (Figure S23), only showed cross peaks between adjacent clusters, such as $\mathrm{Cu}_{6} \mathrm{AgH}$ and $\mathrm{Cu}_{5} \mathrm{Ag}_{2} \mathrm{H}$, in complete accord with the corresponding ${ }^{31} \mathrm{P}_{-}{ }^{31} \mathrm{P}\left\{{ }^{1} \mathrm{H}\right\}$ 2D EXSY data. Clearly, the individual compounds $\mathrm{Cu}_{\mathrm{x}} \mathrm{Ag}_{7-\mathrm{x}}(\mathrm{H})\left\{\mathrm{S}_{2} \mathrm{P}\left(\mathrm{O}^{i} \mathrm{Pr}\right)_{2}\right\}_{6}(\mathrm{x}=0$ - 6) are not static in solution, but are undergoing (dynamic) intermolecular exchange.

We note also that, as shown in Figure S23, cross-peaks within each individual cluster are evident, revealing an intramolecular exchange at least as rapid as the intermolecular process. This is supported by the observation that even at $-60^{\circ} \mathrm{C}$ no changes to the hydride splitting pattern become apparent. ${ }^{11 a}$ Furthermore, as noted above, within each component of the rapidly equilibrating set of clusters, there is only a single ${ }^{109} \mathrm{Ag},{ }^{31} \mathrm{P}$ or ${ }^{77}$ Se resonance, once again supporting the assertion of rapid intramolecular metal scrambling that also brings about averaging of the different $J\left({ }^{1} \mathrm{H}_{-}{ }^{109} \mathrm{Ag}\right)$ values.

These data, together with the observation of a single ${ }^{31} \mathrm{P}$ resonance in each of the starting $\mathrm{Ag}_{7}$ or $\mathrm{Cu}_{7}$ clusters, 1 - 4, and the pseudo octet of octets character of the hydride in 1 , are all consistent with the dynamic nature of the hydride-centered tricapped tetrahedral metal core $\left(\mathrm{H} @ \mathrm{M}_{4} @ \mathrm{M}_{3}\right)$ of $C_{3}$ symmetry, whether it is homo-metallic or hetero-metallic. ${ }^{11 a, 13,16}$ One can speculate as to the mechanism of this fluxional behaviour, and a process involving rapid interchange of the seven metal vertices over eight sites (the central tetrahedron and its four capping positions), ${ }^{17}$ may be a viable option. After mixing, and achieving equilibrium, the product ratios do not change as long as the system remains undisturbed; on the other hand, each compound at the equilibrium state is still undergoing rapid metal exchange within the $\mathrm{S}_{12}\left(\mathrm{Se}_{12}\right)$ icosahedral cage formed by six dichalcogenolate ligands. ${ }^{16-18}$ One might also tentatively suggest a mechanism for the inter-cluster exchange process whereby only a single silver or copper is replaced in the first step. If two clusters collide and there is transfer of a single metal unit onto the vacant fourth cap of the recipient cluster, with subsequent transfer back of a different metal moiety, this may account for the experimental observations.

In principle, since the inter-cluster exchange can be observed on the millisecond scale from the EXSY 2D NMR spectra, an equilibrium constant (Scheme S2) associated with

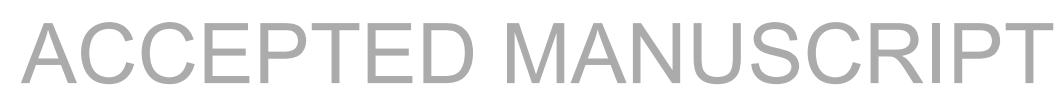


intercluster reactions (Scheme S1) might be established. Theoretically it could be verified by substituting the concentration of each compound into the equation developed. The concentrations derived from the percentage yield (Table S1) can be roughly estimated from the integration of the ${ }^{31} \mathrm{P}$ NMR spectrum; unfortunately, however, only seven species can be detected in the NMR spectrum of the 1:1 $\left(\mathrm{Cu}_{7}\right):\left(\mathrm{Ag}_{7}\right)$ reaction, thus rendering this approach no longer viable.

\section{Crystallographic studies and theoretical calculations of hydride-centered heptanuclear clusters}

Upon crystallizing the products from the reaction having an initial 1:6 molar ratio of $\mathrm{Ag}_{7}, 1: \mathrm{Cu}_{7}, 2$, one might have expected that the major product to be $\mathrm{Cu}_{6} \mathrm{Ag}(\mathrm{H})$ $\left\{\mathrm{S}_{2} \mathrm{P}\left(\mathrm{O}^{i} \mathrm{Pr}\right)_{2}\right\}_{6}$ because of its relatively high intensity in the ${ }^{31} \mathrm{P}$ NMR spectrum. Surprisingly, however, the $\mathrm{X}$-ray structure of 5 a revealed a co-crystallization product consisting of $\left[\mathrm{Cu}_{6} \mathrm{Ag}(\mathrm{H})\left\{\mathrm{S}_{2} \mathrm{P}\left(\mathrm{O}^{i} \mathrm{Pr}\right)_{2}\right\}_{6}\right]$ and $\left[\mathrm{Cu}_{7}(\mathrm{H})\left\{\mathrm{S}_{2} \mathrm{P}\left(\mathrm{O}^{i} \mathrm{Pr}\right)_{2}\right\}_{6}\right]$ in a 2:1 ratio. The phenomenon of co-crystallization in which either different atoms occupy the same site of the lattice, or compositionally distinct clusters co-exist in the lattice, is becoming more common in the atomically precise nanocluster domain. ${ }^{19}$ The cluster $\mathrm{CuAg}_{6}(\mathrm{H})\left\{\mathrm{Se}_{2} \mathrm{P}\left(\mathrm{O}^{i} \mathrm{Pr}\right)_{2}\right\}_{6}$, 6a, was crystallized from the reaction of $\mathrm{Ag}_{7}, 3$, and $\mathrm{Cu}_{7}, 4$, in a 6:1 molar ratio. The metal framework of structures 2, 5a, and $\mathrm{Cu}_{4} \mathrm{Ag}_{3}(\mathrm{H})\left\{\mathrm{S}_{2} \mathrm{P}\left(\mathrm{O}^{i} \mathrm{Pr}\right)_{2}\right\}_{6}{ }^{11 \mathrm{a}}$ and 6 a reveals the same tricapped tetrahedral cage (Figure 5a, S31-S33) encapsulating a hydride in its center. Three structures were further stabilized by dithio-(diseleno-)phosphate ligands (Figure $5 \mathrm{~b}$ ). The Ag atom in $5 \mathrm{a}$ is disordered at three $\mathbf{M}_{\text {tri }}$ and one $\mathbf{M}_{\text {top }}$ positions of a tricapped tetrahedral $\mathbf{M}_{7}$ cage, $\left(\mathrm{Cu}_{3}\right)_{\text {cap }}\left(\mathrm{AgCu}_{3}\right)_{\mathrm{Td}}$ (Figure S32), and the $\mathrm{Cu}$ atom in $6 \mathrm{a}$ is disordered at three $\mathrm{M}_{\text {cap }}$ positions to form a $\left(\mathrm{CuAg}_{2}\right)_{\text {cap }}\left(\mathrm{Ag}_{4}\right)_{\mathrm{Td}}$ cage (Figure S33). Distances of $\mathrm{M}_{\text {tri }}-\mathrm{M}_{\text {tri }}$ and $\mathrm{M}_{\text {top }}-\mathrm{M}_{\text {tri }}$ in 2 are 2.8189(15)-2.8979(17) $\AA$ (avg. 2.8617(16) $\AA$ ) and 2.9266(13)2.6520(13) $\AA$ (avg. 2.9539(13) $\AA$ ), which are smaller than the distances in 5a (2.782(2)3.113(3) A, avg. 2.906(2) A; 3.055(2)-3.112(2) A, avg. $3.085 \AA \AA$ ), $\mathrm{Cu}_{4} \mathrm{Ag}_{3}(\mathrm{H})\left\{\mathrm{S}_{2} \mathrm{P}\left(\mathrm{O}^{i} \mathrm{Pr}\right)_{2}\right\}_{6}{ }^{11 \mathrm{a}}$ (2.9938(4)-3.0148(4) $\AA$, avg. 3.0035(4) $\AA$; 3.0970(5)-

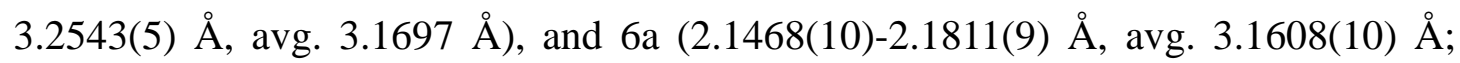
3.0584(8)-3.1396(10) $\AA$, avg. 3.1090(9) $\AA$ ). The largest tetrahedron is in 6a and the smallest one is in 2, and can be attributed to the number of Ag atoms that locate on the tetrahedron: $\left(\mathrm{Cu}_{4}\right)_{\mathrm{Td}}$ in 2, $\left(\mathrm{AgCu}_{3}\right)_{\mathrm{Td}}$ in $5 \mathrm{a},\left(\mathrm{Ag}_{3} \mathrm{Cu}\right)_{\mathrm{Td}}$ in $\mathrm{Cu}_{4} \mathrm{Ag}_{3},{ }^{11 \mathrm{a}}$ and $\left(\mathrm{Ag}_{4}\right)_{\mathrm{Td}}$ in $6 \mathrm{a}$. The relative order of bond lengths has the same trend in other distances such as $\mathrm{M}_{\text {cap }}{ }^{-}$ $\mathrm{M}_{\text {top }}$ and $\mathrm{M}_{\text {cap }}-\mathrm{M}_{\text {tri. }}$. The selected bond lengths in structures 2, 5a, $\mathrm{Cu}_{4} \mathrm{Ag}_{3}(\mathrm{H})\left\{\mathrm{S}_{2} \mathrm{P}\left(\mathrm{O}^{i} \mathrm{Pr}\right)_{2}\right\}_{6}$, and 6 a are listed in Table 3. In general, silver atoms located in the tetrahedral positions in 5a have lower energy than those in capping positions, whereas copper atoms located in capping positions have lower energy than in 
tetrahedral positions. This trend echoes the situation in our previously published sulfur analogues. $^{11 \mathrm{a}}$

DFT calculations at the BP86-D3/ Def2-TZVP level (see Computational details) were performed on simplified models of clusters 3, 4 and 6, namely 3', 4' and 6', in which the isopropoxy groups were replaced by hydrogens. In the case of the heterometallic 6' series, all the positional isomers for each individual composition were considered. Their core topology and energetic data are reported in Figure S34, together with the associated ${ }^{1} \mathrm{H}$ NMR computed chemical shift. The metal cores of the lowest energy isomers within the 6' series are shown in Figure 6. The homometallic species 3' and 4' exhibit a structure of ideal $C_{3}$ symmetry, with a rather regular inner tetrahedron. The $\mathrm{H}-\mathrm{M}_{\text {tri }}$ and $\mathrm{H}-\mathrm{M}_{\text {top }}$ distances are respectively 1.707 and $1.713 \AA$ (3’) and 1.946 and $1.871 \AA$ (4'). The optimized structures of the bimetallic clusters 6' tend to retain as much as possible this structural feature, although some of them are substantially distorted. From the relative energies of the various positional isomers, one can see that the general site preference for $\mathrm{Ag}$ is $\mathrm{M}_{\text {tri }}>\mathrm{M}_{\text {top }}>\mathrm{M}_{\text {cap }}$. The situation is more or less reversed for $\mathrm{Cu}$ with $\mathrm{M}_{\mathrm{cap}} \approx \mathrm{M}_{\text {top }}>\mathrm{M}_{\text {tri. }}$. It is of note that calculations performed the same level of theory on the sulfur analogues of 3', 4' and 6' provided similar results. ${ }^{11 a}$ These results are in line with the X-ray structures of $5 \mathrm{a}$ and $6 \mathrm{a}$, as found previously for their $\mathrm{Cu}_{3} \mathrm{Ag}_{4}$ and $\mathrm{Cu}_{4} \mathrm{Ag}_{3}$ dithiophophate analogues. ${ }^{11 \mathrm{a}}$ On the other hand, the ${ }^{1} \mathrm{H}$ NMR chemical shifts (Figure Sa) computed for the lowest isomers of the $\mathrm{Cu}_{\mathrm{x}} \mathrm{Ag}_{7-\mathrm{x}}$ series do not all fit with the recorded experimental values (Table 1 ). The former show strong dependence on the number of $\mathrm{Cu}$ atoms on the inner tetrahedron, whereas the latter varies with $\mathrm{x}$, i.e. the total number of $\mathrm{Cu}$ atoms in the cluster. This observation can be interpreted on the basis of fast intramolecular exchange between several isomers in solution on the NMR time scale. This is consistent with the fact that each cluster exhibits only a single ${ }^{1} \mathrm{H},{ }^{109} \mathrm{Ag}$ and ${ }^{21} \mathrm{P}$ resonance (see above).

\section{Conclusion}

In conclusion, hydride-centered bimetallic clusters can be conveniently synthesized by simply mixing two hydride-centered homoleptic, homometallic clusters, $\mathrm{Ag}_{7}(\mathrm{H})(\mathrm{dtp} / \mathrm{dsep})_{6}$ and $\mathrm{Cu}_{7}(\mathrm{H})(\mathrm{dtp} / \mathrm{dsep})_{6}$, which are covered by six dichalcogenophosphates. The reaction is spontaneous and fast, resulting in a mixture of $\mathrm{Cu}_{\mathrm{x}} \mathrm{Ag}_{7-\mathrm{x}}(\mathrm{H})\left\{\mathrm{E}_{2} \mathrm{P}\left(\mathrm{O}^{i} \mathrm{Pr}\right)_{2}\right\}_{6}(\mathrm{x}=0-7 ; \mathrm{E}=\mathrm{S}$, Se) within 10 minutes. The tendency to reach equilibrium in solution is driven by a stepwise, one-metal exchange process, as revealed by 2D EXSY NMR experiments. The concentration-dependent experiment confirmed that this chemical equilibrium can be disturbed by changing the stoichiometric ratio of reactants in accord with Le Chatelier's principle. We trust that intercluster reactions leading to the formation of hydride-centered bimetallic clusters 
presented here may provide a new synthetic avenue towards the future discovery of more closed-shell, anion-centered bimetallic or even multimetallic clusters.

In closing, we wonder whether the products identified in the ESI-MS spectra of $\left\{\left[\mathrm{Ag}_{\mathrm{m}} \mathrm{Au}_{\mathrm{n}}(\mathrm{SR})_{18}\right]^{-}, \mathrm{m}+\mathrm{n}=25\right\}^{11-12}$ derived from interparticle reactions also display dynamic equilibrium in solution, analogous to the behavior of the $\mathrm{Cu}_{\mathrm{x}} \mathrm{Ag}_{7-\mathrm{x}}(\mathrm{H})\left\{\mathrm{S}_{2} \mathrm{P}\left(\mathrm{O}^{i} \mathrm{Pr}\right)_{2}\right\}_{6}(\mathrm{x}=1-6)$ system discussed here. Clearly, this merits further investigation and, if true, would provide another important advance in the chemistry of nanomaterials

\section{Conflicts of interest}

The authors declare no competing financial interest.

\section{Acknowledgements}

This work was supported by the Ministry of Science and Technology of Taiwan (MOST 109-2113-M-259-008, 108-2923-M-259-001), and the France-Taiwan ANR-MOST program (project Nanoalloys). We thank Academia Sinica High-Field NMR Center (HFNMRC) for technical support; HFNMRC is funded by Academia Sinica Core Facility and Innovative Instrument Project (AS-CFII-108-112). The GENCI (Grand Equipment National de Calcul Intensif) is acknowledged for HPC resources (Project A0050807367).

\section{References}

1. X. Kang, Y. Li, M. Zhu and R. Jin, Chem. Soc. Rev., 2020, 49, 6443-6514.

2. X. Kang and M. Zhu, Chem. Soc. Rev., 2019, 48, $2422-2457$.

3. Q. Li, J. Chai, S. Yang, Y. Song, T. Chen, C. Chen, H. Zhang, H. Yu and M. Zhu, Small, in press, DOI: $10.1002 /$ smll.201907114.

4. K. Kwak and D. Lee, Acc. Chem. Res., 2019, 52, 12-22.

5. X. Zhou, Y. Li, X. Kang, X. Wei, S. Wang, X. Meng and M. Zhu, J. Phys. Chem. Lett., 2020, 11, 2272-2276.

6. L. Liao, S. Zhou, Y. Dai, L. Liu, C. Yao, C. Fu, J. Yang and Z. Wu, J. Am. Chem. Soc., 2015, 137, 9511-9514.

7. S. Sharma, K. K. Chakrahari, J.-Y. Saillard and C. W. Liu, Acc. Chem. Res., 2018, 24, 14352-14357.

8. W.-T. Chang, P.-Y. Lee, J.-H. Liao, K. K. Chakrahari, S. Kahlal, Y.-C. Liu, M.H. Chiang, J.-Y. Saillard and C. W. Liu, Angew. Chem. Int. Ed., 2017, 56, 10178-10182.

9. W.-T. Chang, S. Sharma, J.-H. Liao, S. Kahlal, Y.-C. Liu, M.-H. Chiang, J.-Y. Saillard and C. W. Liu, Chem. Eur. J., 2018, 24, $14352-14357$.

10. X. Kang, X. Wei, S. Jin, Q. Yuan, X. Luan, Y. Pei, S. Wang, M. Zhu and R. Jin, PNAS, 2019, 116, 18834-18840.

11. K. R. Krishnadas, A. Baksi, A. Ghosh, G. Natarajan and T. Pradeep, Nat. Commun., 2016, 7, 13447.

12. K. R. Krishnadas, A. Baksi, A. Ghosh, G. Natarajan, A. Som and T. Pradeep, Acc. Chem. Res., 2017, 50, 1988-1996.

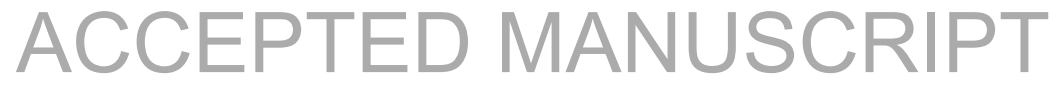


13. B. Huang and Y. Pei, J. Mater. Chem. A, 2020, 8, 10242-10251.

14. S. Bhat, A. Baksi, S. K. Mudedla, G. Natarajan, V. Subramanian and T. Pradeep, J. Phys. Chem. Lett., 2017, 8, 2787-2793.

15. K. R. Krishnadas, A. Baksi, A. Ghosh, G. Natarajan and T. Pradeep, ACS Nano, 2017, 11, 6015-6023.

16. E. Khatun, P. Chakraborty, B. R. Jacob, G. Paramasivam, M. Bodiuzzaman, W. A. Dar and T. Pradeep, Chem. Mater., 2020, 32, 611-619.

17. X. Kang and M. Zhu, Chem. Mater., 2019, 31, 9939-9969.

18. X. Kang, L. Huang, W. Liu, L. Xiong, Y. Pei, Z. Sun, S. Wang, S. Wei and M. Zhu, Chem. Sci., 2019, 10, 8685-8693.

19. Q. Yao, V. Fung, C. Sun, S. Huang, T. Chen, D.-e. Jiang. J. Y. Lee and J. Xie, Nat. Commun., 2018, 9, 1979.

20. R. Poli and M. Peruzzini, Recent Advances in Hydride Chemistry 1st Edition. Elsevier: Amsterdam, 2001, p 557.

21. Q. Tang, Y. Lee, W. Choi, D. Lee and D.-e. Jiang, J. Am. Chem. Soc., 2017, 139, 9728-9736.

22. R. S. Dhayal, W. E. van Zyl and C. W. Liu, Acc. Chem. Res., 2016, 49, 86-95.

23. X. Du and R. Jin, ACS Nano, 2019, 13, 7383-7387.

24. Y.-J. Zhong, J.-H. Liao, T.-H. Chiu, Y.-Y. Wu, S. Kahlal, J.-Y. Saillard and C. W. Liu, Chem. Commun., 2020, 56, 9300-9303.

25. A. N. Desnoyer, A. Nicolay, M. S. Ziegler, N. A. Torquato and T. D. Tilley, Angew. Chem. Int. Ed., 2020, 59, 12769-12773.

26. C. Sun, B. K. Teo, C. Deng, J. Lin, G.-G. Luo, C.-H. Tung and D. Sun, Coord. Chem. Rev., 2021, 427, 213576.

27. S. Takano, H. Hirai, S. Muramatsu and T. Tsukuda, J. Am. Chem. Soc., 2018, 140, 12314-12317.

28. H. Hirai, S. Takano and T. Tsukuda, ACS Omega, 2019, 4, 7070-7075.

29. B. K. Tate, C. M. Wyss, J. Bacsa, K. A. Kluge, L. Gelbaum and J. P. Sadighi, Chem. Sci., 2013, 4, 3068-3074.

30. C. W. Liu, Y.-R. Lin, C.-S. Fang, C. Latouche, S. Kahlal and J.-Y. Saillard, Inorg. Chem., 2013, 52, 2070-2077.

31. A. Lyon, Brit. J. Philos. Sci., 2013, 65, 621-649.

32. N. Yan, N. Xia and Z. Wu, Small, 2020, 2000609.

33. C. A. Hosier, I. D. Anderson and C. J. Ackerson, Nanoscale, 2020, 12, 62396242.

34. G. Salassa, A. Sels, F. Mancin and T. Bürgi, ACS Nano, 2017, 11, 12609-12614.

35. C. Latouche, S. Kahlal, Y.-R. Lin, J.-H. Liao, E. Furet, C. W. Liu and J.-Y. Saillard, Inorg. Chem., 2013, 52, 13253-13262.

36. C. W. Liu, H.-W. Chang, C.-S. Fang, B. Sarkar and J.-Y. Wang, Chem. Commun., 2010, 46, 4571-4573.

37. C. W. Liu, H.-W. Chang, B. Sarkar, J.-Y. Saillard, S. Kahlal and Y.-Y. Wu, Inorg. Chem., 2010, 49, 468-475.

38. P.-K. Liao, K.-G. Liu, C.-S. Fang, C. W. Liu, J. P. Fackler Jr. and Y.-Y. Wu, Inorg. Chem., 2011, 50, 8410-8417.

39. J.-H. Liao, H.-W. Chang, Y.-J. Li, C.-S. Fang, B. Sarkar, W. E. van Zyl and C. W. Liu, Anion templating from a silver(I) dithiophosphate 1D polymer forming discrete cationic and neutral octa- and decanuclear silver(I) clusters. Dalton Trans., 2014, 43, 12380-12389.

40. P.-K. Liao, C.-S. Fang, Y.-Y. Wu and C. W. Liu, J. Clust. Sci., 2019, 30, 11851193.

41. X. Kang and M. Zhu, ACS Materials Lett., 2020, 2, 1303-1314. 
(a) $\mathrm{Cu}_{x} \mathrm{Ag}_{7 \cdot x} \quad \mathrm{x}=0 \quad 1 \quad 2 \quad 3 \quad 456$

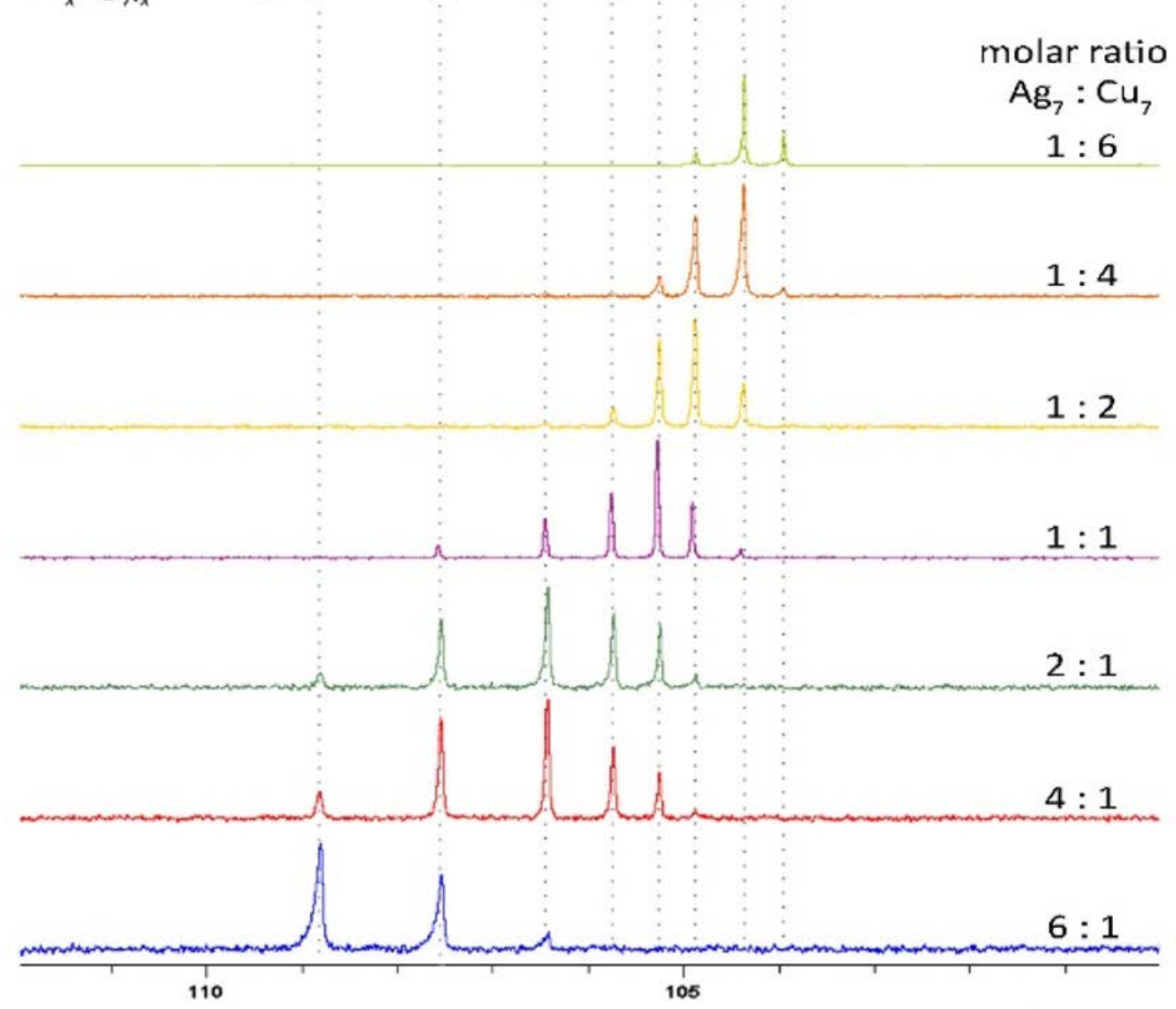

(b)

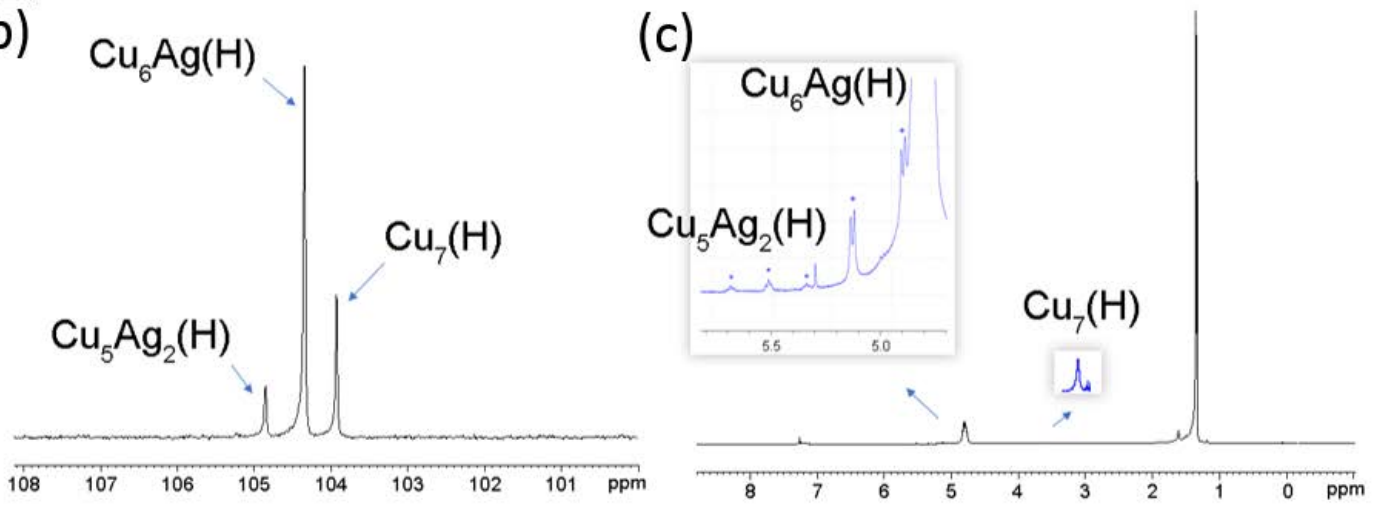

M. Bodiuzzaman, W. A. Dar and T. Pradeep, Small, 2020, 2003981Figure 1. (a) Concentration-dependent ${ }^{31} \mathrm{P}\left\{{ }^{1} \mathrm{H}\right\}$ NMR spectra $(121.49 \mathrm{MHz})$ were performed by mixing 1 and 2 with stoichiometric ratios of 1:6, 1:4, 1:2, 1:1, 2:1, 4:1, and 6:1, respectively. (b) ${ }^{31} \mathrm{P}\left\{{ }^{1} \mathrm{H}\right\}$ and (c) ${ }^{1} \mathrm{H}$ NMR spectra from the reaction of $\mathrm{Ag}_{7}(\mathrm{H})\left\{\mathrm{S}_{2} \mathrm{P}\left(\mathrm{O}^{i} \mathrm{Pr}\right)_{2}\right\}_{6}(\mathbf{1})$ and $\mathrm{Cu}_{7}(\mathrm{H})\left\{\mathrm{S}_{2} \mathrm{P}\left(\mathrm{O}^{i} \mathrm{Pr}\right)_{2}\right\}_{6}$ (2) in a 1:6 molar ratio. 


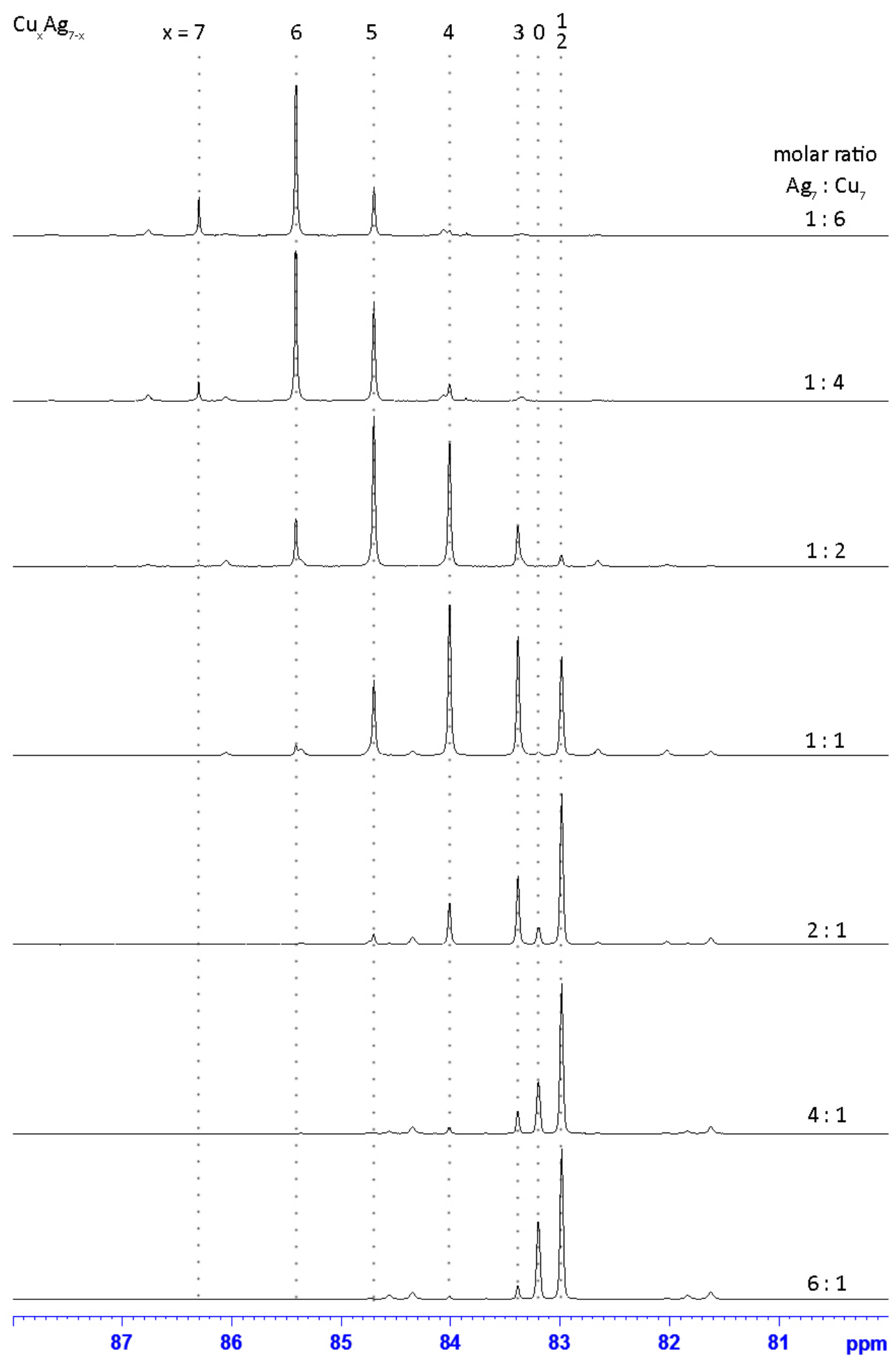

Figure 2. Concentration-dependent ${ }^{31} \mathrm{P}\left\{{ }^{1} \mathrm{H}\right\}$ NMR (242.86 $\left.\mathrm{MHz}\right)$ spectra were performed by mixing 3 and 4 with stoichiometric ratios of 1:6, 1:4, 1:2, 1:1, 2:1, 4:1, and 6:1, respectively. 


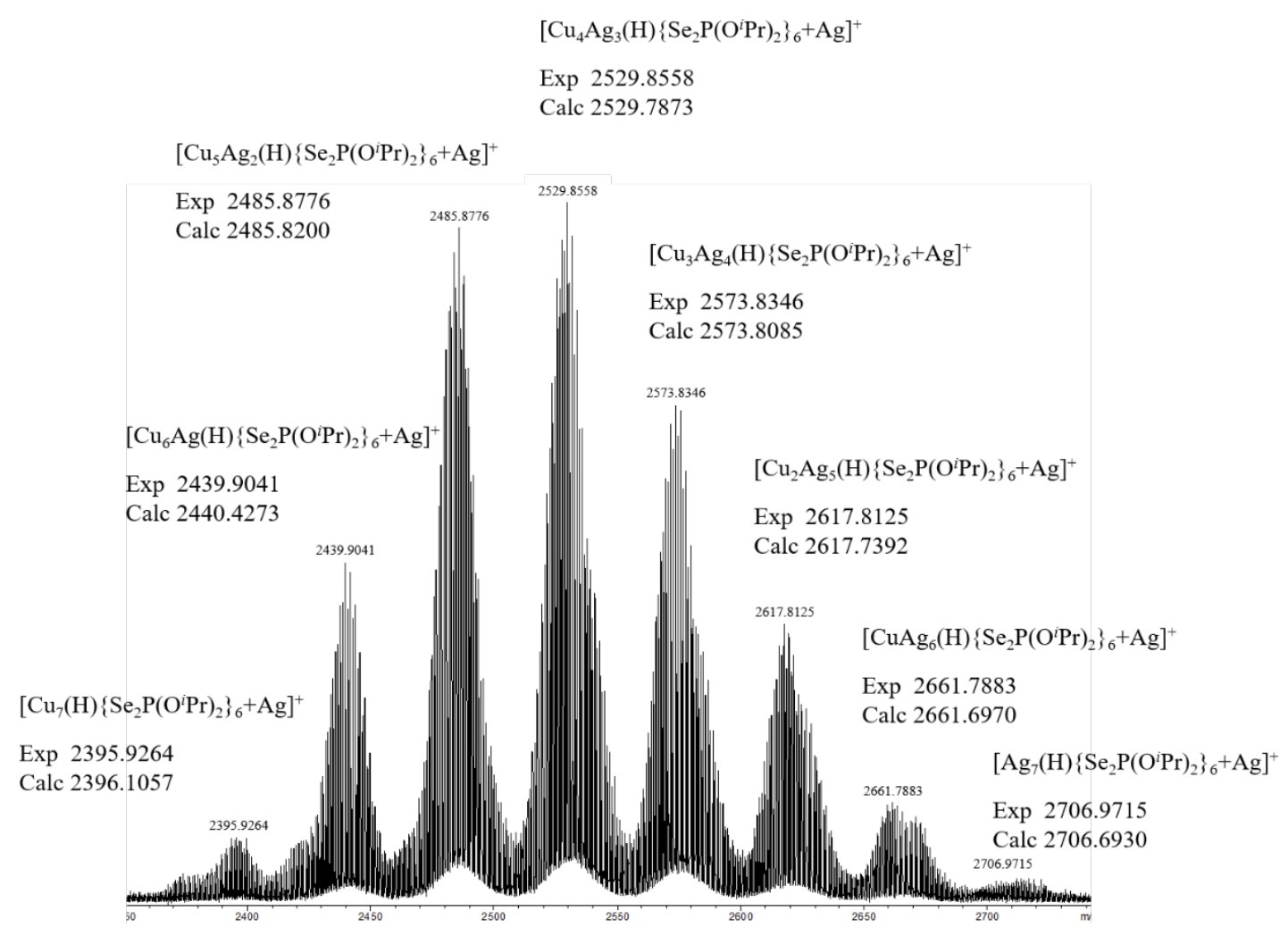

Figure 3. The positive-mode ESI mass spectrum from the reaction of $\mathrm{Ag}_{7}(\mathrm{H})\left\{\mathrm{Se}_{2} \mathrm{P}\left(\mathrm{O}^{i} \mathrm{Pr}\right)_{2}\right\}_{6}$ (3) and $\mathrm{Cu}_{7}(\mathrm{H})\left\{\mathrm{Se}_{2} \mathrm{P}\left(\mathrm{O}^{i} \mathrm{Pr}\right)_{2}\right\}_{6}$ (4) in a 1:1 molar ratio. 
(a)

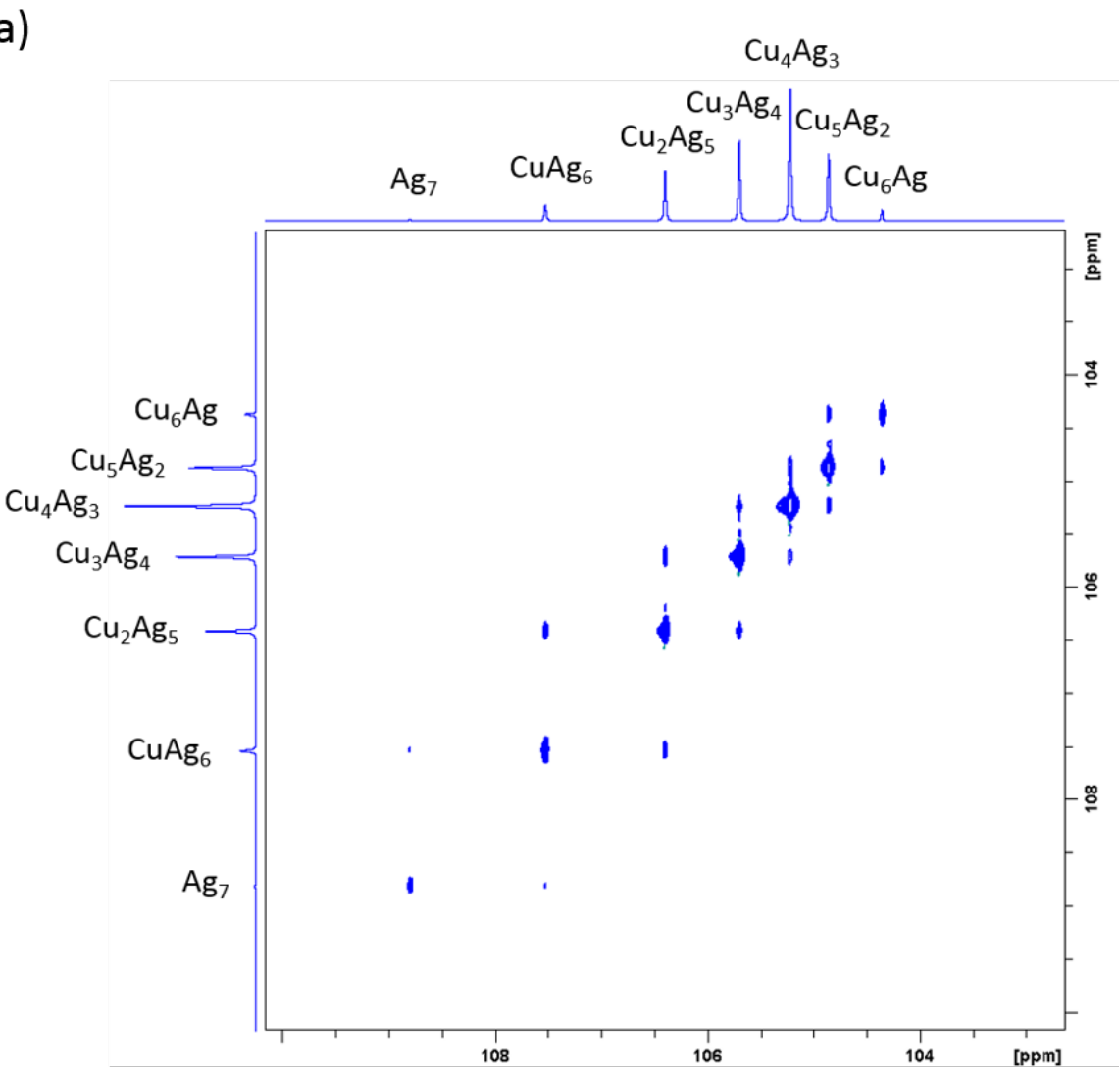

(b)

$$
\mathrm{Cu}_{4} \mathrm{Ag}_{3}
$$

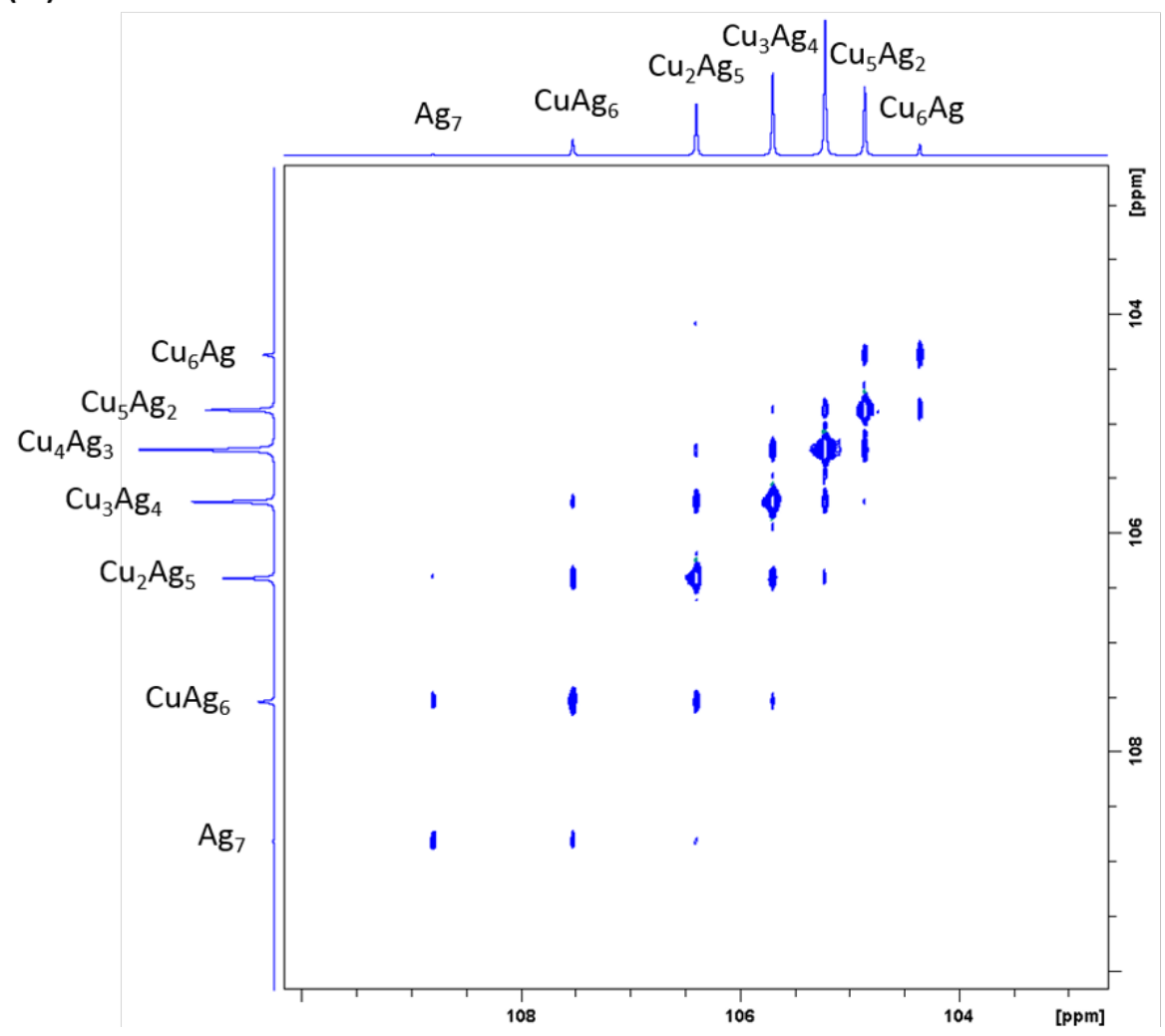

Figure 4. ${ }^{31} \mathrm{P}_{-}{ }^{31} \mathrm{P}\left\{{ }^{1} \mathrm{H}\right\} \quad$ 2D EXSY NMR spectrum of the resulting $\mathrm{Cu}_{\mathrm{x}} \mathrm{Ag}_{7-}$ ${ }_{\mathrm{x}}(\mathrm{H})\left\{\mathrm{S}_{2} \mathrm{P}\left(\mathrm{O}^{i} \mathrm{Pr}\right)_{2}\right\}_{6}(\mathrm{x}=0-6)$ products from the reaction of $\mathbf{1}$ and $\mathbf{2}$ at an equal molar ratio (a) recorded with a mixing time of $400 \mathrm{~ms}$, and (b) $800 \mathrm{~ms}$. 
(a)

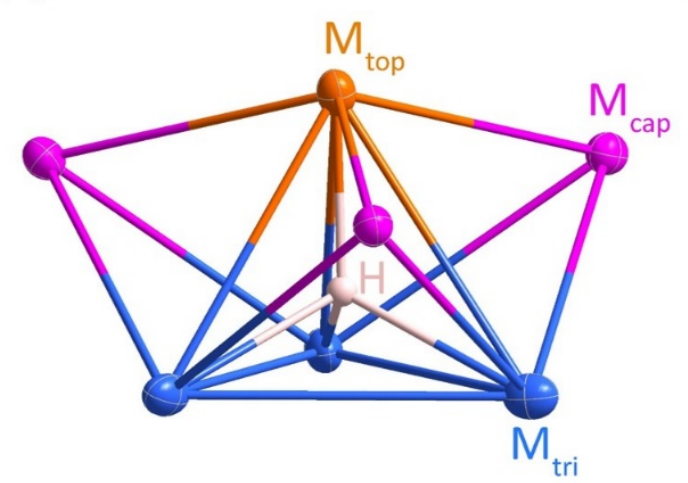

(b)

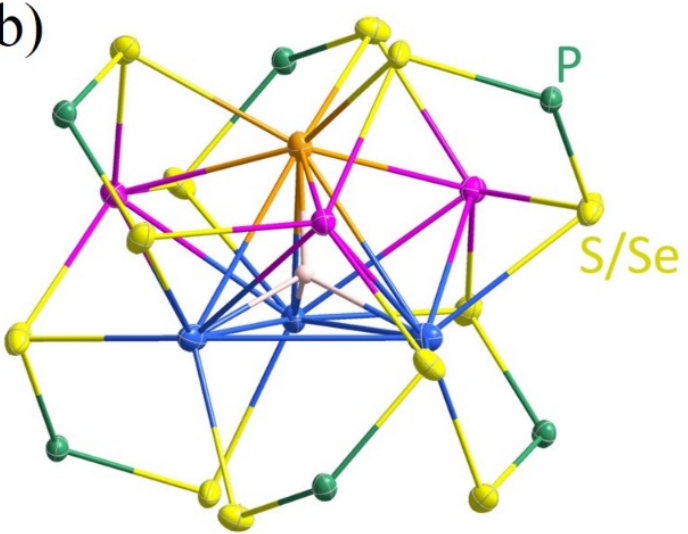

Figure 5. (a) The $\mathrm{M}_{7}$ framework displayed a tricapped tetrahedral cage encapsulated one hydride atom in its center. (b) The $\mathrm{M}_{7} \mathrm{H}$ core is protected by six dithio(diseleno)phosphate ligands with isopropoxy groups omitted for clarity.
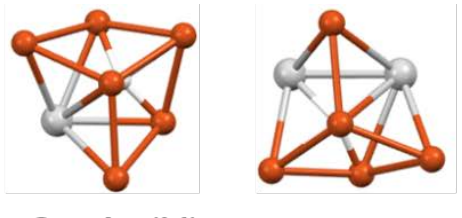

$\mathrm{Cu}_{6} \mathrm{Ag}(\mathrm{H})$

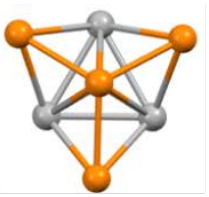

$\mathrm{Cu}_{4} \mathrm{Ag}_{3}(\mathrm{H})$

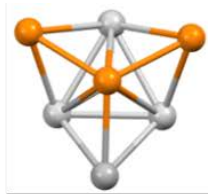

$\mathrm{Cu}_{3} \mathrm{Ag}_{4}(\mathrm{H})$

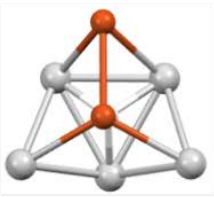

$\mathrm{Cu}_{2} \mathrm{Ag}_{5}(\mathrm{H})$

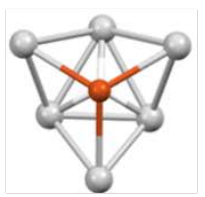

$\mathrm{CuAg}_{6}(\mathrm{H})$

Figure 6. The metal cores of the computed lowest energy isomers within the 6' series. 
Table 1. The chemical shifts and coupling constants of $\mathrm{Cu}_{x} \mathrm{Ag}_{7-\mathrm{x}}(\mathrm{H})\left\{\mathrm{Se} 2 \mathrm{P}\left(\mathrm{O}^{i} \mathrm{Pr}\right)_{2}\right\}_{6}(6)$.

\begin{tabular}{|c|c|c|c|c|c|c|c|c|c|}
\hline & \multicolumn{3}{|c|}{${ }^{1} \mathbf{H}$} & \multicolumn{2}{|c|}{${ }^{109} \mathrm{Ag}$ DEPT } & \multicolumn{2}{|c|}{${ }^{31} \mathbf{P}\left\{{ }^{1} \mathbf{H}\right\}$} & \multicolumn{2}{|c|}{${ }^{77} \mathrm{Se}$} \\
\hline & $\begin{array}{c}\text { Chemical } \\
\text { shift }\end{array}$ & $\begin{array}{c}{ }^{1} J_{1 H-107 A g} \\
(H z)\end{array}$ & $\begin{array}{c}{ }^{1} J_{1 H-109 A g} \\
(H z)\end{array}$ & $\begin{array}{c}\text { Chemical } \\
\text { shift }\end{array}$ & $\begin{array}{c}{ }^{1} J_{1 H-109 A g} \\
(H z)\end{array}$ & $\begin{array}{c}\text { Chemical } \\
\text { shift }\end{array}$ & $\begin{array}{c}{ }^{1} J_{31 P-77 S e} \\
(H z)\end{array}$ & $\begin{array}{c}\text { Chemical } \\
\text { shift }\end{array}$ & $\begin{array}{c}{ }^{1} J_{31 P-77 S e} \\
(H z)\end{array}$ \\
\hline $\mathrm{Cu}_{7}$ & -0.286 & - & - & - & - & 86.3 & 653.6 & 25.3 & 659.1 \\
\hline $\mathrm{Cu}_{6} \mathrm{Ag}_{1}$ & 1.203 & 69.8 & 80.2 & 1036.7 & 83.1 & 85.4 & 655.8 & 24.3 & 656.8 \\
\hline $\mathrm{Cu}_{5} \mathrm{Ag}_{2}$ & 1.890 & 58.3 & 67.0 & 1096.8 & 67.1 & 84.7 & 656.5 & 26.2 & 671.6 \\
\hline $\mathrm{Cu}_{4} \mathrm{Ag}_{3}$ & 2.567 & 57.6 & 66.2 & 1138.7 & 67.6 & 84.0 & 658.8 & 26.8 & 647.6 \\
\hline $\mathrm{Cu}_{3} \mathrm{Ag}_{4}$ & 2.881 & 53.8 & 61.9 & 1158.7 & 62.4 & 83.4 & 660.2 & 28.7 & 660.2 \\
\hline $\mathrm{Cu}_{2} \mathrm{Ag}_{5}$ & 3.175 & 49.2 & 56.6 & 1154.8 & 56.1 & 83.0 & 661.3 & 28.4 & 659.1 \\
\hline $\mathrm{Cu}_{1} \mathrm{Ag}_{6}$ & 3.391 & 42.4 & 48.7 & 1137.5 & 45.9 & 83.0 & 661.3 & 28.4 & 659.1 \\
\hline $\mathbf{A g}_{7}$ & 3.557 & 36.0 & 41.4 & 1123.1 & 39.1 & 83.2 & 662.2 & 27.4 & 660.2 \\
\hline
\end{tabular}


Table 2. Ratios of each compound in 6. The percentage yield is calculated based on the integration of each peak in ${ }^{31} \mathrm{P}$ NMR spectra.

\begin{tabular}{|c|c|c|c|c|c|c|c|}
\hline $\mathbf{C u}_{7}: \mathbf{A g}_{7}$ & $6: 1$ & $4: 1$ & $2: 1$ & $1: 1$ & $1: 2$ & $1: 4$ & $1: 6$ \\
\hline ratio & ${ }^{31} \mathbf{P}(\%)$ & ${ }^{31} P(\%)$ & ${ }^{31} \mathbf{P}(\%)$ & ${ }^{31} P(\%)$ & ${ }^{31} P(\%)$ & ${ }^{31} P(\%)$ & ${ }^{31} \mathbf{P}(\%)$ \\
\hline $\mathrm{Cu}_{7}$ & 12.1 & 5.0 & 0.3 & & & & \\
\hline $\mathrm{Cu}_{6} \mathrm{Ag}_{1}$ & 63.7 & 51.5 & 11.2 & 1.5 & 0.1 & & \\
\hline $\mathrm{Cu}_{5} \mathrm{Ag}_{2}$ & 22.2 & 36.9 & 39.6 & 15.6 & 3.2 & 0.3 & \\
\hline $\mathrm{Cu}_{4} \mathrm{Ag}_{3}$ & 1.9 & 6.6 & 35.3 & 34.3 & 14.0 & 2.6 & 1.1 \\
\hline $\mathrm{Cu}_{3} \mathrm{Ag}_{4}$ & & & 10.4 & 25.5 & 22.2 & 8.7 & 5.1 \\
\hline $\begin{array}{c}\mathrm{Cu}_{2} \mathrm{Ag}_{5}+ \\
\mathrm{Cu}_{1} \mathrm{Ag}_{6}\end{array}$ & & & 3.2 & 23.1 & 53.2 & 64.1 & 59.9 \\
\hline $\mathbf{A g}_{7}$ & & & & & 7.2 & 24.4 & 33.9 \\
\hline
\end{tabular}


Table 3. Selected bond lengths in structures 2, 5a, $\mathrm{Cu}_{4} \mathrm{Ag}_{3}(\mathrm{H})\left\{\mathrm{S}_{2} \mathrm{P}\left(\mathrm{O}^{i} \mathrm{Pr}\right)_{2}\right\}_{6},{ }^{11 \mathrm{a}}$ and $\mathbf{6 a}$.

\begin{tabular}{|c|c|c|c|c|}
\hline & $\mathrm{Cu}_{7}(\mathrm{H})\left\{\mathrm{S}_{2} \mathrm{P}\left(\mathrm{O}^{i} \mathrm{Pr}\right)_{2}\right\}_{6}(2)$ & $\begin{array}{c}\mathrm{Cu}_{6} \mathrm{Ag}(\mathrm{H})\left\{\mathrm{S}_{2} \mathrm{P}\left(\mathrm{O}^{i} \mathrm{Pr}\right)_{2}\right\}_{6} \text { in } \\
\mathbf{5 a}\end{array}$ & $\mathrm{Cu}_{4} \mathrm{Ag}_{3}(\mathrm{H})\left\{\mathrm{S}_{2} \mathrm{P}\left(\mathrm{O}^{i} \mathrm{Pr}\right)_{2}\right\}_{6}$ & $\begin{array}{c}\mathrm{CuAg}_{6}(\mathrm{H})\left\{\mathrm{Se}_{2} \mathrm{P}\left(\mathrm{O}^{i} \mathrm{Pr}\right)_{2}\right\}_{6} \\
\text { (6a) }\end{array}$ \\
\hline $\mathbf{M}_{\text {tri- }} \mathbf{M}_{\text {tri }}(\AA)$ & $\begin{array}{c}\text { 2.8189(15)-2.8979(17), } \\
\text { 2.8617(16) avg. }\end{array}$ & $\begin{array}{l}\text { 2.782(2)-3.113(3) } \\
\text { 2.906(2) avg. }\end{array}$ & $\begin{array}{l}\text { 2.9938(4)-3.0148(4), } \\
\text { 3.0035(4) avg. }\end{array}$ & $\begin{array}{l}\text { 3.1468(10)-3.1811(9), } \\
\text { 3.1608(10) avg. }\end{array}$ \\
\hline $\mathbf{M}_{\text {top}}-\mathbf{M}_{\text {tri }}(\AA)$ & $\begin{array}{c}\text { 2.9266(13)-2.9793(14), } \\
\text { 2.9539(13) avg. }\end{array}$ & $\begin{array}{l}\text { 3.055(2)-3.112(2), } \\
\text { 3.085(2) avg. }\end{array}$ & $\begin{array}{l}\text { 3.0970(5)-3.2543(5), } \\
\text { 3.1697 avg. }\end{array}$ & $\begin{array}{c}\text { 3.0584(8)-3.1396(10), } \\
\text { 3.1090(9) avg. }\end{array}$ \\
\hline $\mathbf{M}_{\text {cap- }} \mathbf{M}_{\text {top }}(\AA)$ & $\begin{array}{c}\text { 2.6116(13)-2.6520(13), } \\
\text { 2.6286(13) avg. }\end{array}$ & $\begin{array}{l}\text { 2.665(2)-2.772(2) } \\
\text { 2.718(2) avg. }\end{array}$ & $\begin{array}{l}\text { 2.7152(6)-2.7312(6), } \\
\text { 2.7235(6) avg. }\end{array}$ & $\begin{array}{l}\text { 2.8986(10)-2.9201(10), } \\
\text { 2.9071(10) avg. }\end{array}$ \\
\hline $\mathbf{M}_{\text {cap-}}-\mathbf{M}_{\text {tri }}(\AA)$ & $\begin{array}{c}\text { 2.6990(13)- 2.7757(13), } \\
\text { 2.7315(13) avg. }\end{array}$ & $\begin{array}{l}\text { 2.712(2)-2.853(2) } \\
\text { 2.785(2) avg. }\end{array}$ & $\begin{array}{c}\text { 2.8950(5)- 3.0118(6), } \\
\text { 2.9418(5) avg. }\end{array}$ & $\begin{array}{l}\text { 2.9993(10)-3.0726(10), } \\
\text { 3.031(1) avg. }\end{array}$ \\
\hline H-Mtop $(\AA)$ & $1.7034(8)$ & $1.76(10)$ & $1.65(2)$ & $1.7387(6)$ \\
\hline H-M $\left.\mathbf{M}_{\text {tri }}(\AA)\right)$ & $\begin{array}{c}\text { 1.7678(11)-1.8821(13), } \\
\text { 1.8128(12) avg. }\end{array}$ & $\begin{array}{c}\text { 1.63(10)-2.06(10), } \\
\text { 1.88(10) avg. }\end{array}$ & $\begin{array}{c}\text { 1.96(3) -2.02(3), } \\
2.00(3) \text { avg. }\end{array}$ & $\begin{array}{c}\text { 1.9803(7)-1.9918(8), } \\
\text { 1.9844(8) avg. }\end{array}$ \\
\hline
\end{tabular}


Table of contents
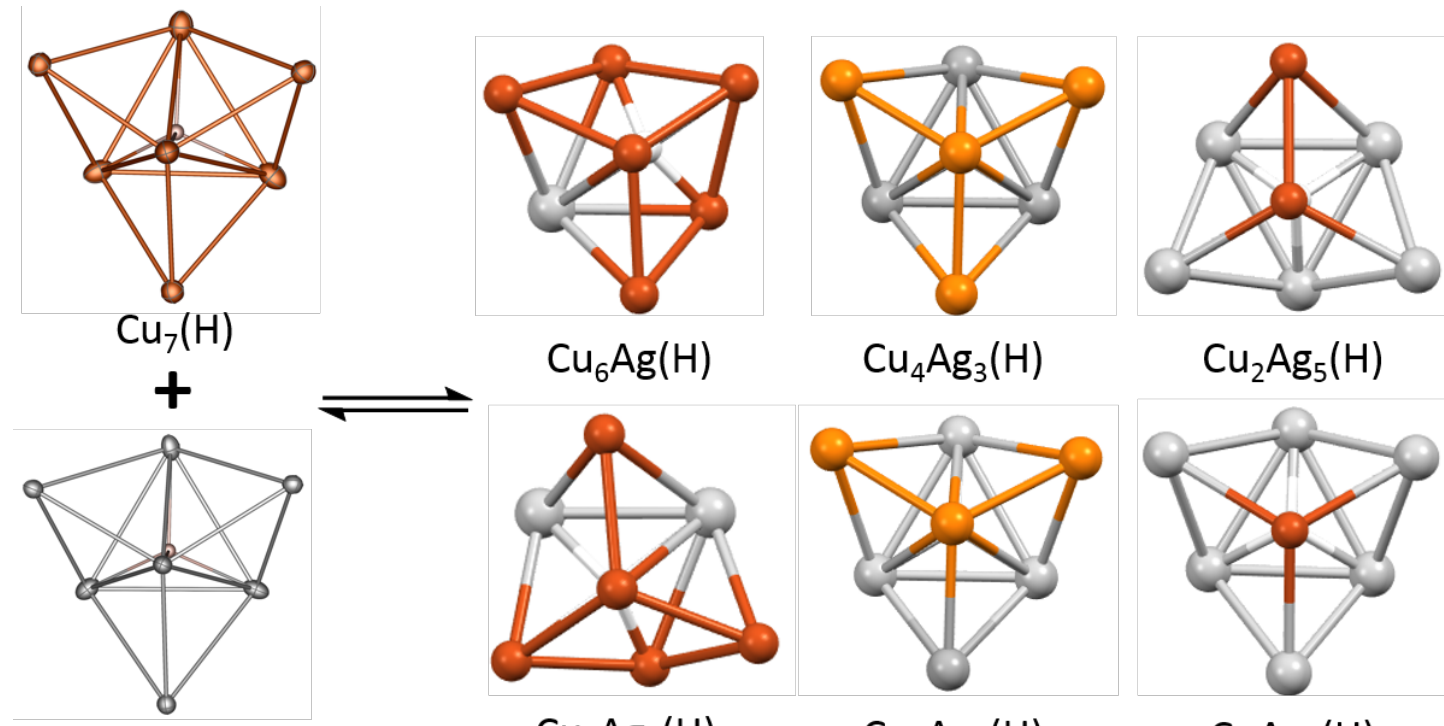

$\mathrm{Ag}_{7}(\mathrm{H})$

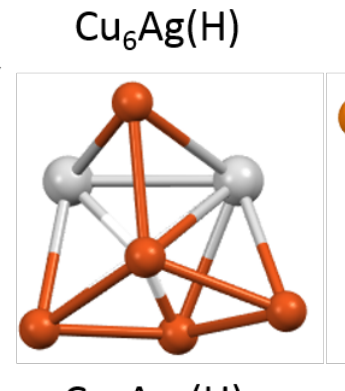

$$
\mathrm{Cu}_{4} \mathrm{Ag}_{3}(\mathrm{H})
$$

$\mathrm{Cu}_{2} \mathrm{Ag}_{5}(\mathrm{H})$
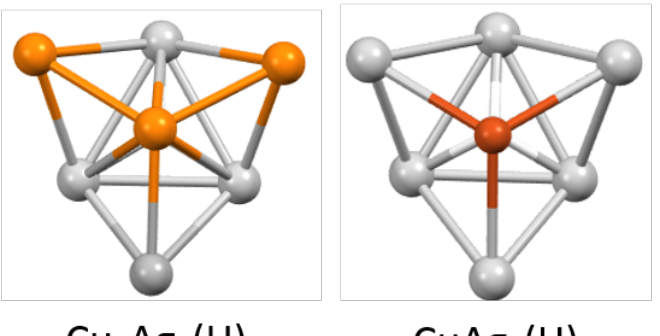

$\mathrm{CuAg}_{6}(\mathrm{H})$ 